\title{
PENINGKATAN KEAKTIFAN SISWA DAN HASIL BELAJAR DENGAN MENGGUNAKAN METODE PEMBELAJARAN PROBLEM BASED LEARNING PADA SISWA SMPN 1 MAYANG KELAS IX
}

\author{
Rohmah Juwita Sari ${ }^{1}$, Anjar Putro Utomo,S.Pd.,M.Ed ${ }^{2}$ \\ ${ }^{1}$ Mahasiswa Program Studi Pendidikan IPA \\ ${ }^{2}$ Dosen Pendidikan IPA FKIP Universitas Jember \\ Program Studi Pendidikan IPA FKIP Universitas Jember \\ Email : juwitas071@gmail.com
}

\begin{abstract}
Abstrak: motivasi siswa untuk cenderung aktif dalam belajar keaktifan di pengaruhi oleh proses belajar mengajar guru. Proses pembelajaran sangat memerlukan keaktifan siswa, tanpa adanya keaktifan siswa maka pembelajaran terkesan membosankan. Keaktifan siswa sebagai unsur terpenting dalam pembelajaran, karena keaktifan akan berpengaruh besar pada keberhasilan proses pembelajaran Proses pembelajaran yang baik akan selalu melibatkan siswa secara aktif dalam setiap kegiatan pembelajaran sehingga dapat membangkitkan motivasi siswa, yang pada akhirnya siswa akan memperoleh prestasi belajar yang optimal. Guru sebagai pembimbing pada dasarnya merupakan upaya membantu siswa yang mengalami masalah belajar agar dapat mengembangkan segenap potensi yang dimilikinya melalui hubungan interpersonal yang akrab dan saling percaya. Guru berusaha membimbing siswa agar dapat menemukan berbagai potensi yang dimilikinya, membimbing siswa agar dapat mencapai dan melaksanakan tugas-tugas perkembangan mereka, sehingga dengan ketercapaian itu mereka dapat tumbuh dan berkembang sebagai individu yang mandiri dan produktif.
\end{abstract}

Kata Kunci: Keaktifan, problem based learning,

Abstract: The motivation of students to tend to be active in learning activeness is influenced by the teaching and learning process of teachers. The learning process really requires student activity, without the activity of students, learning seems boring. Student activity as the most important element in learning, because activeness will have a major effect on the success of the learning process A good learning process will always involve students actively in every learning activity so that it can motivate students, which in the end students will obtain optimal learning achievement. The teacher as a supervisor is basically an effort to help students who experience learning problems in order to develop all the potential they have through interpersonal relationships that are familiar and mutual trust. The teacher strives to guide students in discovering their potential, guiding students to achieve and carry out their development tasks, so that by achieving them they can grow and develop as independent and productive individuals

Keywords: activeness, problem based learning

\section{PENDAhUluan}

Dalam proses belajar mengajar terjadi aktivitas guru dan siswa. Hal ini yang memotivasi siswa untuk cenderung aktif dalam belajar keaktifan. Proses pembelajaran sangat memerlukan keaktifan siswa, tanpa adanya keaktifan siswa maka pembelajaran terkesan membosankan. Keaktifan siswa sebagai unsur terpenting dalam pembelajaran, karena keaktifan akan berpengaruh besar pada keberhasilan proses pembelajaran. Semakin tinggi keaktifan siswa, maka keberhasilan proses belajarpun harus semakin tinggi. Dalam proses pembelajaran selain keaktifan siswa hal yang penting adalah hasil belajar siswa. Hasil belajar merupakan kemampuankemampuan yang dimiliki siswa setelah menerima pengalaman belajarnya. Hasil belajar dapat dilihat melalui kegiatan evaluasi yang bertujuan untuk mendapatkan data pembuktian yang akan menunjukkan tingkat kemampuan siswa dalam mencapai tujuan pembelajaran. Untuk mencapai itu semua diperlukan adanya model pembelajaran yang tepat. Model pembelajaran menjadi pedoman seorang guru bagaimana mengarahkan muridnya dalam sebuah pembelajaran. Terdapat banyak model pembelajaran yang dapat diterapkan seorang guru dalam 
proses belajar mengajar. Model pembelajaran digunakan sebagai prosedur sistematis dalam mengorganisasikan pengalaman belajar untuk mencapai tujuan belajar. Sebagai seorang guru harus mampu memilih model pembelajaran yang tepat bagi peserta didik. Karena itu dalam memilih model pembelajaran, guru harus memperhatikan keadaan atau kondisi siswa, bahan pelajaran serta sumber-sumber belajar yang ada agar penggunaan model pembelajaran dapat diterapkan secara efektif dan menunjang keberhasilan belajar siswa. Seorang guru diharapkan memiliki motivasi dan semangat pembaharuan dalam proses pembelajaran yang dijalaninya. Belajar tidak hanya penguasaan konsep teori mata pelajaran saja, tapi juga penguasaan kebiasaan, persepsi, kesenangan, minat bakat, penyesuaian sosial, macam-macam keterampilan, cita-cita, keinginan dan harapan. Selain itu sebagai seorang guru juga harus memperhatikan materi yang akan disampaikan dengan model pembelajaran yang tepat. Dalam lingkup sekolah salah satu materi yang dieluhkan para siswa adalah pelajaran matematika. Matematika merupakan salah satu mata pelajaran yang menduduki peranan penting dalam dunia pendidikan. Matematika dalam pelaksanaan pendidikan diajarkan di institusi-institusi pendidikan, baik ditingkat SD, SMP, SMA, hingga perguruan tinggi. Salah satu karakteristik matematika adalah mempunyai obyek kajian yang bersifat abstrak. Sifat abstrak ini menyebabkan banyak siswa mengalami kesulitan dalam menghayati dan memahami konsep-konsep matematika. Rendahnya kemampuan siswa dalam mempelajari matematika ini juga dieluhkan oleh para guru matematika di SMPN 1 Mayang. Rendahnya kemampuan kemampuan matematis dipengaruhi oleh beberapa faktor salah satunya adalah rasa kecemasan matematis siswa. Keberhasilan belajar siswa salah satunya dipengaruhi oleh faktor sekolah. Di mana guru sebagai salah satu personal dalam sekolah berperan penting untuk pencapaian keberhasilan tersebut. Kemampuan guru dalam mengajar harus benar-benar diperhatikan.
Sebab kualitas siswa akan ditentukan oleh baik dan buruknya proses pembelajaran yang dilakukan oleh guru pada tiap-tiap sekolah. Proses pembelajaran yang baik akan selalu melibatkan siswa secara aktif dalam setiap kegiatan pembelajaran sehingga dapat membangkitkan motivasi siswa, yang pada akhirnya siswa akan memperoleh prestasi belajar yang optimal. Guru sebagai pembimbing pada dasarnya merupakan upaya membantu siswa yang mengalami masalah belajar agar dapat mengembangkan segenap potensi yang dimilikinya melalui hubungan interpersonal yang akrab dan saling percaya. Guru berusaha membimbing siswa agar dapat menemukan berbagai potensi yang dimilikinya, membimbing siswa agar dapat mencapai dan melaksanakan tugas-tugas perkembangan mereka, sehingga dengan ketercapaian itu mereka dapat tumbuh dan berkembang sebagai individu yang mandiri dan produktif. Hal ini perlu adanya model pembelajaran yang dapat menarik siswa agar mau mendengarkan pelajaran yang disampaikan serta mudah memahami apa yang telah disampaikan oleh guru. Sehingga penting bagi seorang guru untuk menentukan model pembelajaran yang akan dipakai guna meningkatkan keaktifan siswa dan hasil belajar yang baik dalam mata pelajaran Matematika.

\section{METODE PENELITIAN}

Jenis penelitian ini adalah Penelitian Tindakan Kelas (PTK) atau Classroom Action Research (CAR) yang dilakukan secara kolaborasi guru dan peneliti. Menurut Kunandar (2011: 45) PTK adalah penelitian tindakan yang dilakukan dengan tujuan memperbaiki mutu praktik pembelajaran di kelas. Penelitian tindakan kelas termasuk penelitian kualitatif meskipun data yang dikumpulkan bisa saja bersifat kuantitatif, dimana uraiannya bersifat deskriptif dalam bentuk kata-kata. Peneliti merupakan instrumen utama dalam pengumpulan data, proses sama pentingnya dalam produk. Penelitian dilaksanakan di SMPN 1 Mayang Kelas IX A. Tahun Pelajaran 2018/2019 yang 
berjumlah 32 siswa yang terdiri dari 22 siswa perempuan dan 10 siswa laki-laki. Waktu penelitian dilaksanakan selama 2 minggu namun tidak berkala hanya ketika ada jadwal kuliah yang kosong yaitu mulai 19 Oktober tahun 2018. Sedangkan obyek penelitian adalah pembelajaran matematika dalam usaha peningkatan keaktifan siswa dan hasil belajar dengan menggunakan metode pembelajaran Problem Based Learning, meskipun saya adalah jurusan IPA kebetulan saya di suruh membantu dalam pelajaran Matematika. Prosedur penelitian dalam penelitian tindakan kelas ini akan meliputi empat tahap yaitu perencanaan (planning), tindakan (action), pengamatan (observation), dan refleksi (reflection). Pada tahap perencanaan (planning) langkah-langkah nya adalah membuat surat progam pembelajaran dari Fakultas keguruan dan ilmu pendidikan. Sedangkan untuk tahap tindakan (action) peneliti menyiapkan langkah-langkah sebagai berikut: (a) meminta ijin kepada kepala sekolah untuk melakukan penelitian, (b) membuat lembar penilaian proses dan hasil belajar untuk siswa, (e) membuat lembar observasi. Langkah selanjutnya adalah pengamatan (observation), menurut Sugiyono (2011: 145) bahwa observasi sebagai teknik pengumpulan data mempunyai ciri yang spesifik bila dibandingkan dengan yang lain, yaitu wawancara dan kuesioner. Mahmud (2011: 185) menyatakan bahwa tes adalah rangkaian pertanyaan atau alat lain yang digunakan untuk mengukur keterampilan, pengetahuan, intelegensi, kemampuan, atau bakat yang dimiliki oleh individu atau kelompok. Sedangkan menurut Arikunto (2009: 53), Tes merupakan alat atau yang digunakan untuk mengetahui atau mengukur sesuatu dalam suasana, dengan cara dan aturan-aturan yang sudah ditentukan. Dokumentasi adalah teknik pengumpulan data yang tidak langsung ditujukan pada subjek penelitian, tetapi melalui dokumen (Mahmud, 2011: 183). Sedangkan catatan lapangan digunakan untuk mencatat peristiwa dan pengalaman penting yang terjadi pada proses pembelajaran yang belum ada dalam observasi. Instrumen penelitian dikembangkan oleh peneliti dengan guru pembimbing dengan menjaga validitas isi. Dalam pelaksanaan penelitian ini, digunakan pedoman yaitu observasi tindak mengajar disesuaikan dengan rencana pembelajaran, observasi tindak belajar berkaitan dengan penalaran dan hasil belajar siswa dalam pembelajaran matematika dan keterangan tambahan yang berkaitan dengan tindak mengajar maupun tindak belajar yang belum tersaji. Langkah yang terakhir refleksi (reflection) yaitu perealisasian dari tahapan-tahapan yang telah disiapkan mulai dari perencanaan (planning), tindakan (action), hingga pengamatan (observation). Penelitian tindakan kelas (PTK) merupakan penelitian yang bersifat reflektif. Kegiatan penelitian berangkat dari permasalahan riil yang dihadapi oleh praktisi pendidikan dalam tugas pokok dan fungsinya masingmasing, kemudian direfleksikan alternatif pemecahan masalahnya dan ditindak lanjuti dengan tindakan-tindakan nyata yang terencana dan terukur.

\section{HASIL DAN PEMBAHASAN}

Penerapan model pembelajaran PBL pada siswa kelas IX A untuk meningkatkan keaktifan dan hasil belajar. Langkah-langkah model pembelajaran PBL dalam pembelajaran ini dilakukan sebanyak 2 kali pertemuan. Setiap pertemuan terdapat pada langskah-langkah berikut, yaitu: a) Siswa dikelompokkan menjadi 4 orang, guru memberikan materi pembelajaran matematika yang bekaitan dengan kehidupan sehari-hari kepada siswa tersebut, b) Setiap kelompok mengobservasi materi pembelajaran tersebut, c) Kelompok diberi kesempatan bertanya kepada guru tentang materi yang belum dipahami, d) Kelompok kemudian menalar materi pembelajaran yang diberikan guru tersebut, e) Setelah itu siswa mencoba mengaplikasikan materi tersebut, g) Salah satu kelompok diharap ke depan kelas untuk mempresentasikan hasil diskusi dan kelompok yang lain memberi tanggapan dan pertanyaan, (h) guru memberikan tes individu sebagai 
hasil belajar siswa, g) Terakhir guru dan siswa menyimpulkan materi yang telah didapat dari hasil diskusi tersebut. Pada penelitian ini pengumpulan data menggunakan metode dokumentasi. Metode dokumentasi digunakan untuk mengetahui hasil belajar matematika. Dalam pelaksanaan tindakan peneliti melaksanakan pembelajaran sesuai dengan skenario yang telah dibuat. Peneliti dalam kegiatan observasi mengacu pada lembar observasi. Pada tahap yang terakhir yaitu refleksi peneliti melakukan evaluasi dan membahas hasil evaluasi tersebut dan mencermatinya. Setelah kelompok tadi selesai mempresentasikan hasil pekerjaannya, kelompok lain mengajukan pertanyaan jika ada jawaban atau penjelasan dari hasil presentasi yang kurang paham dan menjawab pertanyaan dari guru jika kelompok lain kurang aktif mengajukan pertanyaan terhadap hasil presentasi temannya. Keaktifan dan hasil belajar siswa dalam pembelajaran matematika mengalami perubahan yang positif. Adanya peningkatan keaktifan dan hasil belajar dalam pembelajaran matematika dapat dilihat dari indikatorindikator yang nampak antara lain: a) Mengajukan pertanyaan, b) Mengerjakan soal latihan di depan kelas, c) Mengemukakan ide, d) menjawab pertanyaan dan e) Hasil belajar. Permasalahan yang akan dicari jawabannya dalam penelitian ini adalah: "Adakah peningkatan keaktifan dan hasil belajar dengan menunggunakan pembelajaran metode pembelajaran Problem Based Learning pada siswa SMPN 1 Mayang kelas IX A." Tindakan yang dilakukan peneliti dengan dibantu oleh guru matematika sekaligus guru IPA adalah meningkatkan keaktifan dan hasil belajar dalam pembelajaran matematika dengan model pembelajaran PBL. Keaktifan dan hasil belajar dalam pembelajaran matematika mengalami peningkatan yang baik. Sebelum dilakukan tindakan, hanya siswa tertentu saja yang aktif mengajukan pertanyaan, mengerjakan soal latihan di depan kelas, menjawab pertanyaan, mengemukakan idenya. Hal ini disebabkan karena pembelajaran matematika lebih didominasi oleh guru sehingga siswa kurang berpatisipasi aktif dalam pembelajaran. Keaktifan dan hasil belajar matematika mulai meningkat pada tindakan pertemuan ke 2 . Adapun data data yang diperoleh dari pengamatan selama proses tindakan kelas terhadap keaktifan dan hasil belajar matematika siswa SMPN 1 Mayang kelas IX A. Penerapan model pembelajaran Problem Based Learning dapat meningkatkan keaktifan dan hasil belajar siswa yang dapat dilihat melalui indikator indikatornya, yaitu:

a. Keaktifan siswa dalam mengajukan pertanyaan

Adanya peningkatan siswa yang mengajukan pertanyaan pada indikator ini dapat diukur dari banyaknya siswa yang aktif mengangkat tangan untuk mengajukan pertanyaan terhadap guru saat KBM berlangsung. Guru memotivasi keaktifan siswa dalam mengajukan pertanyaan dengan penerapan model PBL melalui kegiatan diskusi yang berhubungan dengan kehidupan sehari-hari siswa. Dalam penelitian ini siswa yang aktif mengajukan pertanyaan soal matematika terhadap guru meningkat. Hal ini dapat dilihat dari keaktifan siswa mengangkat tangan untuk mengajukan pertanyaan sebelum dilakukan tindakan ada 3 siswa $(8,82 \%)$ ada 6 siswa $(17,64 \%)$ pada pertemuan minggu minggu pertama, dan pada Pertemuan ke Dua minggu ada 20 siswa $(58,82 \%)$. Pada penelitian ini dapat dilihat bahwa setelah adanya tindakan keaktifan siswa dalam mengajukan pertanyaan meningkat secara signifikan setelah diterapkannya model pembelajaran PBL.

b. Keaktifan siswa dalam mengerjakan soal latihan di depan kelas

Siswa yang aktif mengerjakan soal latihan di depan kelas diukur 
dari keaktifan siswa mengangkat tangan untuk mengerjakan soal cerita di depan kelas dengan pemecahan yang sederhana sampai yang sulit. Penambahan nilai juga diberikan kepada siswa supaya siswa lebih termotivasi untuk mengerjakan soal latihan di depan kelas. Dalam penelitian ini siswa yang aktif mengerjakan soal latihan di depan kelas meningkat. Hal ini dapat dilihat dari keaktifan siswa dalam mengerjakan soal latihan di depan kelas sebelum dilakukan tindakan ada 4 siswa $(11,76 \%)$, Pertemuan minggu pertama ada 10 siswa $(29,41 \%)$, dan pada pertemuan minggu ke II ada 22 siswa $(64,70 \%)$. Pada penelitian ini dapat dilihat bahwa setelah adanya tindakan keaktifan mengerjakan soal latihan dalam indikator keaktifan siswa dalam mengerjakan soal latihan di depan kelas dapat dikatakan meningkat secara signifikan setelah diterapkannya model pembelajaran PBL.

c. Keaktifan siswa dalam menjawab pertanyaan

Peningkatan keaktifan siswa
dalam indikator ini dapat memotivasi siswa untuk aktif menjawab pertanyaan yang didapat dan menerangkan jawaban kepada teman-teman sekelasnya. Siswa yang aktif menjawab pertanyaan dapat dilihat dari keaktifan siswa yang mengangkat tangan untuk menjawab pertanyaan dari guru pada saat pembelajaran. Dalam penelitian ini siswa yang aktif menjawab pertanyaan meningkat. Hal ini dapat dilihat dari sebelum dilakukan tindakan ada 12 siswa $(35,29 \%)$, pada minggu pertemuan ke-I ada 17 siswa $(50,00 \%)$, dan pada minggu pertemuan ke-II ada 25 siswa $(82,35 \%)$. Pada penelitian ini dapat dilihat bahwa setelah adanya tindakan keaktifan menjawab pertanyaan dalam indikator keaktifan siswa dalam

menjawab pertanyaan dapat
dikatakan meningkat

siswa yang aktif mengangkat tangan untuk mengemukakan ide kepada guru pada saat KBM berlangsung. Dalam penelitian ini keaktifan siswa dalam mengemukakan ide meningkat. Hal ini dapat dilihat dari keaktifan siswa dalam mengemukakan ide sebelum dilakukan tindakan ada 4 siswa $(11,76 \%)$, pada minggu pertemuan ke-I ada 7 siswa $(20,58 \%)$, dan pada minggu pertemuan ke-II ada 16 siswa $(47,05 \%)$. Pada penelitian ini dapat dilihat bahwa setelah adanya tindakan keaktifan mengemukakan ide dalam indicator keaktifan siswa dalam mengemukakan ide dapat dikatakan meningkat secara signifikan setelah diterapkannya model pembelajaran PBL. Dalam penelitian ini terbukti bahwa keaktifan dan hasil belajar siswa dalam pembelajaran mengalami peningkatan yang signifikan berdasarkan indikator kinerja yang telah ditetapkan oleh peneliti dan guru IPA dan Matematika SMPN 1 Mayang.

\section{SIMPULAN}

Kualitas siswa yang meningkat yaitu keaktifan dan hasil belajar matematika dalam pembelajaran matematika pada siswa SMPN 1 Mayang kelas IX A. Adanya peningkatan keaktifan dan hasil belajar siswa SMPN 1 Mayang kelas IX A. melalui model pembelajaran PBL dapat dilihat dari peningkatan beberapa indikator seperti : Keaktifan siswa dalam mengajukan pertanyaan, Keaktifan siswa dalam mengerjakan soal latihan di depan kelas, Keaktifan siswa dalam menjawab pertanyaan, Keaktifan siswa dalam mengemukakan ide.

\section{SARAN}


Sebaiknya sebelum melakukan penelitian maupun observasi penulis lebih memahami apa yang akan diteliti agar tidak memperlambat waktu pengerjaan ataupun penelitian dan observasinya.

\section{UCAPAN TERIMA KASIH.}

Penulis ingin mengucapkan banyak banyak puji Syukur kepada Allah S.W.T yang meridhoi penelitian serta observasi di SMPN 1 Mayang hingga selesai dengan keadaan yang sehat wal afiat. Serta titak lupa pula untuk memanjatkan Sholawat serta salam kepada junjungan kami nabi besar Muhammad S.A.W. Sebelumnya saya ingin berterima kasih banyak untuk keluarga besar SMPN 1 Mayang yang memperbolehkan saya untuk melakukan observasi disana. Serta saya ingin mengucapkan banyak banyak terima kasih kepada bapak Edo Selaku guru IPA dan
Matematika yang telah mau membantu saya dalam penelitian ini serta membantu dalam mengumpulkan data data yang saya inginkan. Serta saya ucapkan banyak banyak terima kasih untuk orang tua saya yang mendoakan saya serta terus memberikan saya semangat serta membantu saya baik bathil maupun bathin.

\section{DAFTAR PUSTAKA}

Arikunto, Suharsimi. 2009. Dasar-Dasar Evaluasi Pendidikan (Edisi Revisi). Jakarta: Bumi Aksara.

Kunandar. 2011. Penelitian Tindakan Kelas. Jakarta : Rajawali Press

Mahmud. 2011. Metode Penelitian Pendidikan. Bandung: Pustaka Setia.

Sugiyono. 2011. Metode Penelitian Kuantitatif, Kualitatif dan R \& D. Bandung: $\quad$ Alfabeta. 